\title{
Effect of ensiling a total mixed ration on feed quality for cattle in smallholder dairy farms ${ }^{\#}$
}

\author{
Efecto de ensilar una ración totalmente mezclada sobre la calidad nutricional \\ para el ganado en pequeñas explotaciones lecheras
}

\author{
G Bretschneider*, J Mattera, A Cuatrin, D Arias, R Wanzenried \\ Instituto Nacional de Tecnología Agropecuaria, Estación Experimental Agropecuaria Rafaela, Santa Fe, Argentina.
}

\begin{abstract}
RESUMEN
El objetivo de este estudio fue determinar el impacto del ensilado sobre la composición química y las características fermentativas y sensoriales de una ración totalmente mezclada (TMR). La planta entera de maíz (WPC) fue ensilada sola, como control, o combinada con otros alimentos disponibles en la región. Los alimentos ensilados se almacenaron en minisilos durante 75 días. No se observó desarrollo de moho. La variable de color se calificó como buena para ambos tratamientos, mientras que el olor se calificó como moderado para el ensilaje de TMR y bueno para el ensilaje de WPC. No hubo diferencias en el patrón y la tasa de disminución del pH entre los tratamientos. Sin embargo, los valores promedios de $\mathrm{pH}$ difirieron $(\mathrm{P}<0,01$; 3.81 vs. 4.38) entre los ensilajes de TMR y de WPC, respectivamente. La concentración de materia seca (MS) $(36,58$ vs. $64,25 \%$; $\mathrm{P}=0,001)$, proteína bruta $(9,89$ vs. $18,15 \% ; \mathrm{P}=0,005)$ y energía metabolizable $(\mathrm{P}=0,03 ; 2,51$ vs. $2,80 \mathrm{Mcal} / \mathrm{kg} \mathrm{MS})$ resultó, como era esperado, mayor para el ensilaje de TMR. El contenido de fibra detergente neutro disminuyó durante el almacenamiento, aunque a una velocidad diferente $(\mathrm{P}=0,04)$ para cada tratamiento. Expresada como porcentaje/día, la tasa de disminución fue - $-0,16$ y $-0,05$ para los ensilajes de WPC y de TMR, respectivamente. Se sugiere que el ensilado de TMR es una tecnología simple y de bajo costo que podría ayudar a mejorar, mediante una mejor alimentación del ganado lechero, los ingresos económicos de los pequeños productores lecheros.
\end{abstract}

Palabras claves: ración totalmente mezclada, ensilaje de maíz, lechería, pequeños productores.

\section{SUMMARY}

The aim of this study was to assess the impact of ensiling a total mixed ration (TMR) on chemical composition, fermentation and sensory characteristics. Whole-plant corn (WPC) was ensiled alone, as a control, or in combination with other available local feeds. Ensiled feedstuffs were manually mixed and packed into mini-silos. Thereafter, they were stored and allowed to ferment for 75 days. Mould growth was not observed. Color was scored as good for both silage treatments, whereas odor was scored as moderate for TMR silage and good for WPC silage. The pattern and rate of decrease of pH during the storage was not different between silage treatments. However, mean $\mathrm{pH}$ values were different $(\mathrm{P}<0.01 ; 3.81$ vs. 4.38) between WPC- and TMRsilages, respectively. Relative to WPC silage, the concentration of dry matter (DM) (36.58 vs. $64.25 \%$; $=0.001)$, crude protein $(9.89$ vs. $18.15 \%$; $\mathrm{P}$ $=0.005)$ and metabolizable energy $(P=0.03 ; 2.51$ vs. $2.80 \mathrm{Mcal} / \mathrm{kg} \mathrm{DM})$ was higher for TMR silage, as expected. Furthermore, the neutral detergent fibre content decreased along the storage but at a different rate $(\mathrm{P}=0.04)$ for each silage treatment. The rate of decrease, expressed as percentage/day, was -0.16 and -0.05 for WPC- and TMR- silage, respectively. Overall, TMR silage had adequate attributes to cope with dairy cow requirements. It is suggested that the ensiling of TMR, composed by locally available feedstuffs, is a simple and low cost technology that could aid smallholder dairy to improve their net daily income.

Key words: total mixed ration, corn silage, dairy, smallholder.

\section{INTRODUCTION}

Dairying is widely recognised as an important means of inducing socio-economic transformation in rural areas (Devendra 1999, Garg et al 2013). In Argentina, smallscale dairies have gradually been replaced by grain crop production (mainly soybean Glycine max), most likely because the latter is considered a more profitable and

\footnotetext{
Accepted: 03.09.2014.

\# SANFE- 1261102. Desarrollo territorial sustentable de la zona mixta de la Provincia de Santa Fe, Argentina.

* bretschneider.g@inta.gob.ar; bretschneider3@hotmail.com
}

simpler activity. To mitigate this unwished phenomenon, and to avoid people migration from rural to urban areas, it is required that small-scale dairy farms improve their net daily income. In the long term, technology is the most relevant force for increasing productivity (Salem and Smith 2008). In this regard, it has been suggested that technologies successfully developed for enhancing animal production in large-scale farms should be adapted for small-scale ones (Ashbell et al 2001).

Compared with individual component feeding systems, total mixed ration (TMR) has several nutritional advantages, such as increasing milk yield and reducing acidosis risk, among others (Coppock et al 1981). However, TMR technology is not readily available for small producers 
because they can not afford to buy mixers, tractors, etc. or to construct facilities for TMR feeding. In response to this situation, Chinese researchers proposed to ensile TMR in bales as a suitable alternative to intensify small-scale farms (Wang et al 2010). Furthermore, Japanese (Wang and Nishino, 2008) and Israeli (Weinberg et al 2011) researchers also performed studies on this topic. In view of this, the aim of this study was to assess the impact of ensiling a TMR, composed of locally available feed resources, on chemical composition, fermentation and sensory characteristics.

\section{MATERIAL AND METHODS}

\section{ENSILING EXPERIMENT}

Corn hybrid (La Tijereta, LT 624 MGRR2, Monsanto, Argentina) was grown at the Dairy Production Experimental Unit of the National Institute of Agricultural Technology, Rafaela, Province of Santa Fe, Argentina (31 ${ }^{\circ} 12^{\prime} \mathrm{S} ; 61^{\circ}$ 30 ' W). On May, 2012, whole corn plants were harvested at $25.4 \%$ dry matter (DM) (half-milk line stage) and chopped to achieve a theoretical cut length of $19 \mathrm{~mm}$. Harvesting was performed with a forage harvester equipped with a 6-row corn head and a kernel processor (Class Jaguar 850, Harsewinkel, Germany). On the harvesting day, whole-plant corn (WPC) was ensiled alone, as a control, or in combination with other feeds. The TMR consisted of WPC $(20.0 \%)$, chopped alfalfa hay $(9.0 \%)$, ground corn $(34.0 \%)$, soybean expeller $(13.0 \%)$, sunflower expeller (11.0\%) and cotton seed (13.0\%) on a DM basis. Ensiled materials were manually mixed, and packed into mini-silos that were $10 \mathrm{~cm}$ in diameter and $24 \mathrm{~cm}$ in length polyvinyl chloride pipes sealed with caps on both ends. Air from ensiled material was removed by compacting with a handheld tamper. Mini-silos were stored in a well-ventilated building ( 18 to $25^{\circ} \mathrm{C}$ ) and allowed to ferment for 5,8 , $12,19,45$ and 75 days. To determine the sample size, $\mathrm{pH}$ value was considered as the critical variable. Assuming a mean $\mathrm{pH}$ difference between treatments of at least 0.5 $\mathrm{pH}$ units, a probability value of 0.05 and a power of 0.80 , the minimum number of mini-silos required to achieve the desired statistical properties was two (Hedeker et al 1999). Therefore, two mini-silos from each treatment were opened and sampled by storing day. Upon opening silos, silages were examined for mould spots and analysed for sensory changes. Ensiled feed samples were frozen at $-20{ }^{\circ} \mathrm{C}$ for further analysis.

\section{ANALYTICAL PROCEDURES}

For chemical composition, frozen samples were thawed and dried in a forced-air oven at $65^{\circ} \mathrm{C}$ until constant weight to determine DM content. Samples were then grounded in a Wiley Mill (Arthur H. Thomas, Philadelphia, PA, USA) to pass through a 1-mm screen and analysed for neutral detergent fibre (aNDF; assayed with sodium sulfite, with a heat stable alpha amylase and expressed inclusive of residual ash, [Komarek 1993]), acid detergent fibre (ADF; expressed inclusive of residual ash, AOAC 1990; \# 973.18), ether extract (EE; AOAC 1998; \# 920.39), acid detergent lignin (ADL, AOAC 1990; \# 973.18), total nitrogen (Kjeldhal method 976.05 of AOAC 1998), crude protein (CP; total nitrogen x 6.25) and ash (AOAC 1990; \# 942.05). Nonfibrous carbohydrates (NFC) were calculated using the following equation: $100-(\%$ aNDF $+\% \mathrm{CP}+\% \mathrm{EE}+\%$ ash $)(\mathrm{NRC} 2001)$. The total digestible nutrient (TDN) and the metabolizable energy (ME) values of ensiled feeds were estimated using the NRC (2001) program. Fermentation was assessed through $\mathrm{pH}$ evolution during the storage period. A total of $50 \mathrm{~g}$ (as-fed basis) of each ensiled feed sample was macerated with 50 $\mathrm{ml}$ distilled water using a blender. The macerated sample was filtered and acidity of the filtrate was assessed by $\mathrm{pH}$ meter (ORION-model 250A) with combination electrode (ORION-model 9256BN). Data were expressed on a DM basis, except for DM and $\mathrm{pH}$.

The sensory analysis of silages was assessed in terms of color and odor, according to a 4-point scale modified from Romero et al 2011. The higher scores denoted better quality: Good quality (4): yellowish-green to light-brown color, pleasant ester odor. Moderate quality (3): yellowish-green to brown color, slight butyric acid and ammonia odor. Poor quality (2): very dark green to grey color, strong butyric acid and ammonia odor. Very poor quality (1): brown to black color, burnt sugar or tobacco odor. Ensiled materials were also visually examined, under a stereo microscope (BOECO-Model BTB-3C), for presence or absence of mould growth. Assessment was carried out by two independent operators.

\section{STATISTICAL ANALYSIS}

Chemical composition and $\mathrm{pH}$ data were analysed in a completely randomised design, as repeated measurements by ANOVA using the NLME package of R (2012). Sensory properties were analyzed by Cochran-Mantel-Haenszel test using the PROC FREC of SAS (2004). The experimental unit was the mini-silo and a $5 \%$ significance level was used.

\section{RESULTS AND DISCUSSION}

Spoilage of silage is associated with oxygen penetration into the silo during preparation, storage or feeding (Ruxton et al 1975). In this study, mould growth was not observed in any of the mini-silos, suggesting that, once sealed, they were stored under airtight conditions. The sensory analysis is recognized as a useful alternative to assess the expected overall nutritive value of silage, mainly for smallholders which have economic constraints to carry out animal feed analysis (Kavana 2012). As shown in table 1, the color score was not modified $(\mathrm{P}=0.56)$ by TMR silage, relative to 
Table 1. Color and odor score relative frequency for each treatment, total mixed ration (TMR) silage vs. whole plant corn (WPC) silage.

Frecuencia relativa de los puntajes de color y olor para los ensilajes de ración totalmente mezclada (TMR) y de planta entera de maíz (WPC).

\begin{tabular}{|c|c|c|c|c|}
\hline \multirow{3}{*}{ Score } & \multicolumn{2}{|c|}{ Color } & \multicolumn{2}{|c|}{ Odor } \\
\hline & TMR silage & WPC silage & TMR silage & WPC silage \\
\hline & \multicolumn{4}{|c|}{ Relative frequency ${ }^{1}$} \\
\hline 3 & 0.33 & 0.25 & 0.67 & 0.25 \\
\hline 4 & 0.67 & 0.75 & 0.33 & 0.75 \\
\hline Odd ratio & \multicolumn{2}{|c|}{$1.1(0.8-1.5)^{2}$} & \multicolumn{2}{|c|}{$2.7(1.3-6.0)^{2}$} \\
\hline P-value & \multicolumn{2}{|c|}{0.56} & \multicolumn{2}{|c|}{$<0.01$} \\
\hline
\end{tabular}

$1 n=12$ for each treatment.

2 Confidence interval $(95 \%)$.

Table 2. Effect of treatment (total mixed ration [TMR] silage vs. whole plant corn [WPC] silage), sampling day and treatment per sampling day interaction on chemical composition of feedstuffs ensiled in mini-silos.

Efecto del tratamiento (ensilaje de ración totalmente mezclada [TMR] vs. ensilaje de planta entera de maíz [WPC]), día de muestreo y de la interacción del tratamiento por el día de muestreo sobre la composición química de los materiales ensilados en minisilos.

\begin{tabular}{|c|c|c|c|c|c|c|}
\hline \multirow{2}{*}{ Item $^{1}$} & \multicolumn{2}{|c|}{ Treatment (Trt) } & \multirow{2}{*}{ SEM $^{2}$} & \multicolumn{3}{|c|}{$\mathrm{P}$-value } \\
\hline & TMR silage & WPC silage & & Trt & Day & Trt x Day \\
\hline $\mathrm{pH}$ & $4.38^{\mathrm{a}}$ & $3.81^{\mathrm{b}}$ & 0.12 & $<0.01$ & 0.10 & 0.95 \\
\hline $\mathrm{DM}(\%)$ & $64.25^{\mathrm{a}}$ & $36.58^{\mathrm{b}}$ & 1.47 & $<0.01$ & 0.20 & 0.53 \\
\hline $\mathrm{CP}(\%)$ & $18.15^{\mathrm{a}}$ & $9.89^{\mathrm{b}}$ & 1.01 & $<0.01$ & 0.87 & 0.65 \\
\hline $\operatorname{aNDF}(\%)$ & $34.49^{\mathrm{a}}$ & $44.84^{\mathrm{b}}$ & 3.22 & 0.03 & $<0.01$ & 0.04 \\
\hline $\operatorname{ADF}(\%)$ & 19.18 & 21.73 & 2.22 & 0.33 & 0.35 & 0.18 \\
\hline $\operatorname{ADL}(\%)$ & 3.37 & 2.88 & 0.66 & 0.09 & 0.26 & 0.28 \\
\hline $\mathrm{EE}(\%)$ & 7.68 & 6.48 & 0.90 & 0.07 & 0.58 & 0.60 \\
\hline Ash $(\%)$ & 6.44 & 7.93 & 0.84 & 0.14 & 0.27 & 0.10 \\
\hline $\operatorname{NFC}(\%)$ & 33.24 & 30.85 & 3.94 & 0.36 & $<0.01$ & 0.03 \\
\hline ME (Mcal/kg DM) & $2.80^{\mathrm{a}}$ & $2.51^{\mathrm{b}}$ & 0.10 & 0.03 & 0.07 & 0.19 \\
\hline $\mathrm{TDN}(\%)$ & 73.73 & 68.68 & 2.45 & 0.07 & 0.06 & 0.17 \\
\hline
\end{tabular}

a,b For the same row, means with different superscripts differ $(\mathrm{P}<0.05)$.

1 DM, dry matter; CP, crude protein; aNDF, neutral detergent fiber; ADF, acid detergent fiber; ADL, acid detergent lignin; EE, ether extract; NFC, nonfibrous carbohydrates; ME, metabolizable energy; TDN, total digestible nutrients.

2 Standard error of the mean.

WPC silage. Both silage treatments scored as good quality for color. On the other hand, TMR silage had significantly lower odor score $(\mathrm{P}=0.003)$ than WPC silage. For odor, WPC- and TMR- silages were scored as good and moderate quality, respectively. Overall, the sensory attributes for TMR silage are considered acceptable for feeding.

The $\mathrm{pH}$ and chemical composition of silage treatments are reported in table 2. TMR silage had higher $\mathrm{pH}$ than WPC silage ( 4.38 vs. $3.81 ; \mathrm{P}=0.007$ ). Usually, corn silage $\mathrm{pH}$ values range between 3.7 and 4.2 (Bretschneider et al 2001, 2007, Kung and Shaver 2001). In this study, pH values were close to the lower and the upper range values cited above. The treatment $\mathrm{x}$ sampling day interaction was not significant $(\mathrm{P}=0.95$; table 2$)$, meaning that the pattern and rate of decrease of $\mathrm{pH}$ during the storage was not different between silage treatments. Acid detergent fibre, ADL, EE, TDN and ash did not differ $(\mathrm{P}>0.05)$ between treatments. Relative to WPC silage, DM (36.58 vs. $64.25 \% ; \mathrm{P}=0.001), \mathrm{ME}$ content $(2.51$ vs. $2.80 \mathrm{Mcal} / \mathrm{kg}$ $\mathrm{DM} ; \mathrm{P}=0.03)$ and $\mathrm{CP}(9.89$ vs. $18.15 \% ; \mathrm{P}=0.005)$ content were higher in TMR silage. For optimal dry matter intake, the DM concentration of TMR should be in the range of 45.0 to $55.0 \%$ (Hutjens 2001). In this study, TMR silage was drier than recommended. It is suggested to decrease the content of drier feedstuffs in favor of wetter ones. In this regard, if cost-effective and available, agro-industrial by-products (e.g. wet distillers grains) may be an option to include in TMR (Nishino et al 2003). By a meta-analysis that examined a large number of diets formulated for lactation dairy cows, Hristov et al (2004) determined that dietary 
ME content ranges from 2.14 to $2.96 \mathrm{Mcal} / \mathrm{kg} \mathrm{DM}$. Both silage treatments had $\mathrm{ME}$ values contented in this range.

As shown in table 2, aNDF was different $(\mathrm{P}=0.03)$ between treatments. However, as a significant treatment $\mathrm{x}$ day interaction was found $(\mathrm{P}=0.04)$, it was analysed. For both silage treatments, aNDF content decreased along the storage but at a different rate (figure 1A). The rate of decrease, expressed as percentage/day, was -0.16 and -0.05 for WPC- and TMR- silage, respectively. As previously indicated by Wang et al (2010), this result was most probably due to the enzymatic breakdown of cellulose and hemicelluloses during storage. A treatment $\mathrm{x}$ day interaction was also registered for NFC $(\mathrm{P}=0.03$; table 2). In contrast to the findings for aNDF, the content of NFC increased along the storage (figure 1B). The rate of increase, expressed as percentage/day, was different between WPC- $(+0.20)$ and TMR- $(+0.04)$ silage. The NFC content is a calculated value based on nutrient percentages subtracted from $100 \%$ of DM (NRC 2001). Therefore, its increase may be mainly explained by the change in aNDF content through the storage ( $r=0.89$ for TMR and $r=$ 0.97 for WPC; $\mathrm{P}<0.01)$.

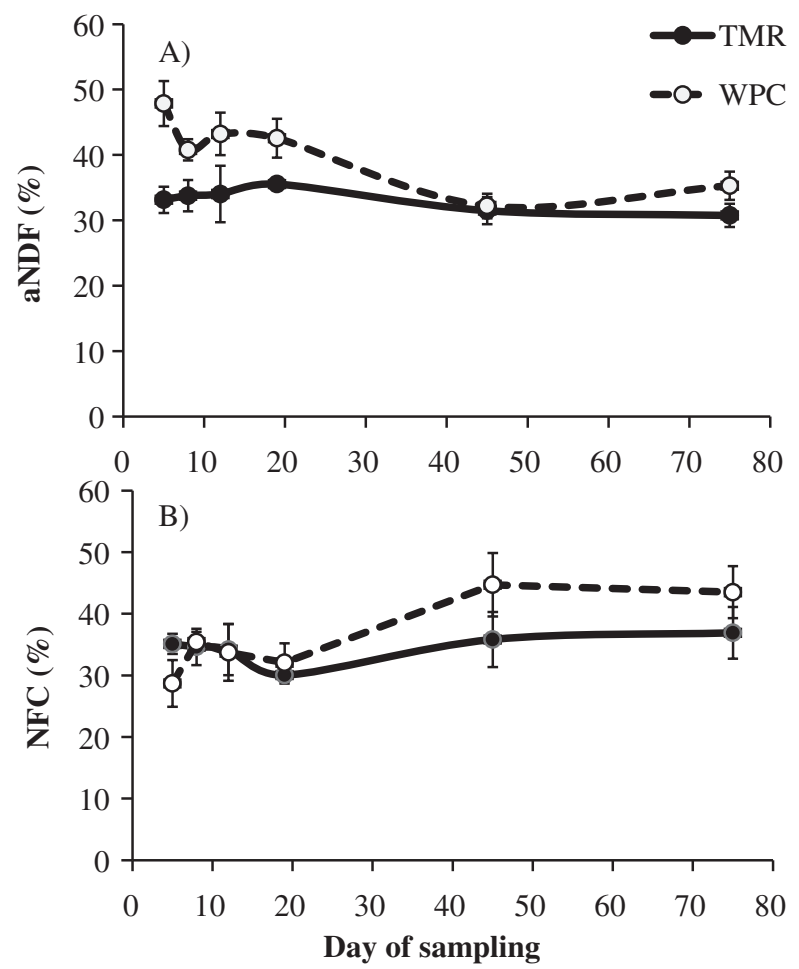

Figure 1. Evolution of the content of neutral detergent fibre (aNDF; A) and nonfibrous carbohydrates (NFC; B) for the total mixed ration (TMR) silage vs. whole plant corn (WPC) silage during the storage period.

Evolución del contenido de fibra de detergente neutro (aNDF; A) y carbohidratos no fibrosos (NFC; B) para los ensilajes de ración totalmente mezclada (TMR) y de planta entera de maíz durante el almacenaje.
A small bag ensiling technology was promoted as a useful and low cost tool to improve production in smallholder livestock farms (Reiber et al 2009). The carrying capacity described for commercial small bags ranges from 40 (Reiber et al 2009) to $500 \mathrm{~kg}$ (Scribano 2012). Results from laboratory silos should be field-tested using commercial bags before being applied at farms (Cherney et al 2004). The implementation of a ration balancing programme has been suggested to improve the productivity of smallholder dairy (Garg et al 2013). In this regard, TMR silage technology could cope with this challenge by formulating balanced rations according to the nutritional needs of cattle by using the feedstuffs available in each region.

\section{REFERENCES}

AOAC, Association of Official Analytical Chemists. 1990. Official Methods of Analysis. $15^{\text {th }}$ ed. AOAC, Arlington, VA, USA.

AOAC, Association of Official Analytical Chemists. 1998. Official Methods of Analysis. $16^{\text {th }}$ ed. AOAC, Washington, DC, USA.

Ashbell G, T Kipnis, M Titterton, Y Hen, A Azrieli, ZG Weinberg. 2001. Examination of a technology for silage making in plastic bags. Anim Feed Sci Technol 91, 213-222.

Bretschneider G, FJ Santini, JP Fay, C Faverin. 2001. Effects of maize silage supplementation before lucerne grazing on the occurrence of bloat in cattle. $N Z J$ Agric Res 44, 241-251.

Bretschneider G, M Peralta, FJ Santini, JP Fay, C Faverin. 2007. Influence of corn silage supplementation before alfalfa grazing on ruminal environment in relation to the occurrence of frothy bloat in cattle. Anim Feed Sci Technol 136, 23-37.

Cherney DJR, JH Cherney, WJ Cox. 2004. Fermentation characteristics of corn forage ensiled in mini-silos. J Dairy Sci 87, 4238-4246.

Coppock CE, DL Bath, B Harris. 1981. From feeding to feeding systems. J Dairy Sci 64, 1230-1249.

Devendra C. 1999. Dairying in integrated farming systems. In: Falvey L, Chantalakhana C (eds). Smallholder Dairying in the Tropics. International Livestock Research Institute, Nairobi, Kenya, Pp 277-288.

Garg MR, PL Sherasia, BM Bhanderi, BT Phondba, SK Shelke, HPS Makkar. 2013. Effects of feeding nutritionally balanced rations on animal productivity, feed conversion efficiency, feed nitrogen use efficiency, rumen microbial protein supply, parasitic load, immunity and enteric methane emissions of milking animals under field conditions. Anim Feed Sci Technol 179, 24-35.

Hedeker D, RD Gibbons, C Waternaux. 1999. Sample size estimation for longitudinal designs with attrition: comparing time-related contrasts between two groups. J Educ Behav Stat 24, 70-93.

Hristov AN, WJ Price, B Shafii. 2004. A meta-analysis examining the relationship among dietary factors, dry matter intake, and milk and milk protein yield in dairy cows. J Dairy Sci 87, 2184-2196.

Hutjens M. 2001. Successful feeding systems for dairy. Hoard W.D. \& Sons, Fort Atkinson, WI, USA.

Kavana PY. 2012. Utilization of sugar cane juice as additive for guinea grass silage making in eastern coast of Tanzania. Res Opin Anim Vet Sci 2, 166-172.

Komarek AR. 1993. An improved filtering technique for the analysis of neutral detergent fiber and acid detergent fiber utilizing the filter bag technique. Publication $N^{o} 101$. Ankom Tech. Corp., Fairport, NY, USA.

Kung L, R Shaver. 2001. Interpretation and use of silage fermentation analysis reports. Focus on Forage 3, 1-5.

Nishino N, H Harada, E Sakaguchi. 2003. Evaluation of fermentation and aerobic stability of wet brewers' grains ensiled alone or in combination with various feeds as a total mixed ration. J Sci Food Agric 83, 557-563. 
NRC, National Research Council. 2001. Nutrient requirement of dairy cattle. $7^{\text {th }}$ revised ed. National Academic Press, Washington, DC, USA.

R. 2012. $R$ version 3.1-109. The R Foundation for Statistical Computing, Vienna, Austria.

Reiber C, R Schultze-Kraft, M Peters, V Hoffmann. 2009. Potential and constraints of little bag silage for smallholders-results and experiences from Honduras. Expl Agric 45, 209-220.

Romero LA, MC Gaggiotti, EA Comerón. 2011. Análisis sensoriales. En: Zubizarreta J (ed). Manual forrajero 2011. San Francisco, Córdoba, Argentina, Pp 54-55.

Ruxton IB, BJ Clark, P McDonald. 1975. A review of the effects of oxygen on ensilage. J Br Grassld Soc 30, 23-30.

Salem HB, T Smith. 2008. Feeding strategies to increase small ruminant production in dry environments. Small Rumin Res 77, 174-194.

SAS. 2004. SAS OnlineDoc ${ }^{\circledR}$ 9.1.3. SAS Institute Inc., Cary, NC, USA.
Scribano V. 2012. Minisilos, para no quedarse afuera. En: Chimicz J (ed). Serie Lechería Extrapampeana: Ideas, Propuestas y Soluciones para la Lechería Extrapampeana. Boletín Técnico del Instituto Nacional de Tecnología Agropecuaria, Rafaela, Argentina.

Wang F, N Nishino. 2008. Ensiling of soybean curd residue and wet brewers grains with or without other feeds as a total mixed ration. J Dairy Sci 91, 2380-2387.

Wang J, JQ Wang, DP Bu, WJ Guo, ZT Song, JY Zhang. 2010. Effect of storing total mixed rations anaerobically in bales on feed quality. Anim Feed Sci Technol 161, 94-102.

Weinberg ZG, Y Chen, D Miron, Y Raviv, E Nahim, A Bloch, E Yosef, M Nikbahat, J Miron. 2011. Preservation of total mixed rations for dairy cows in bales wrapped with polyethylene stretch film - A commercial scale experiment. Anim Feed Sci Technol 164, $125-129$. 